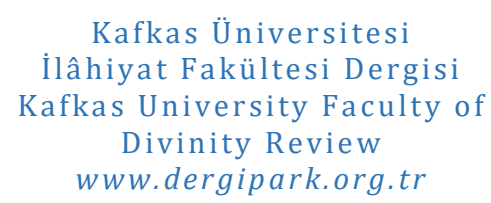

Doi 10.17050/kafkasilahiyat.991418

The Issue of Rational Possibility of Forgiveness of Unbelief in Maturidiyya İbrahim BAYRAM*

\begin{abstract}
It is known that Maturidiyya and Ash 'ariyya, who united under the umbrella of Ahl al-Sunnah differed on some issues. Among the issues that this first sect considers different from the second is the mental permissibility of the disbeliever's forgiveness. While Maturidiyya took a negative attitude in this regard, Ash'ariyya allowed this. The sects, who allied themselves when such a thing was not possible in terms of the relevant texts, disagreed on the rational possibility of the matter, depending on their approaches on some other issues. Maturidis, who argue that blasphemy cannot be the subject of amnesty in the mental plan, except for the religious dimension, have applied to various evidences in this context. The relevant evidence, most of which was put forward by Imam Maturidi himself, is basically based on the understanding that Allah is wise, and accordingly the forgiveness of unbelief, which is unwise, cannot be performed by Him. In detail, it was based on reasons such as the fact that unbelief does not contain any good, that it is in an eternal position of faith, that it is qubh in essence and that its prohibition cannot be considered to be lifted, that its forgiveness is not in an appropriate position of forgiveness, and the aforementioned amnesty will put good and evil in an equal position.
\end{abstract}

Keywords: Kalām, Maturidiyya, Unbelief, Forgiveness, Rational Possibility.

\title{
Mâtürîdiyye’de Küfrün Affının Aklen Cevazı Meselesi
}

\section{İbrahim BAYRAM}

$\ddot{O} z$

Ehl-i sünnet çatısı altında birleșen Mâtürîdiyye ile Eș'ariyye'nin bazı konularda fikir ayrıllğına düştükleri bilinmektedir. İşbu ilk mezhebin ikincisinden farklı düşündüğü konular arasında kâfirin affinın aklen cevazı meselesi de yer almaktadır. Bu hususta Mâtürîdiyye olumsuz bir tavır alırken, Eş'ariyye ise buna imkân tanımıştır. İlgili naslar itibariyle böyle bir şeyin mümkün olmadiğında ittifak eden mezhepler, diğer kimi konulardaki yaklaşımlarına bağlı olarak işin akli cevaziyetinde ihtilafa düşmüşlerdir. Küfrün șer'i boyutu dışında akli planda da affa konu olamayacağını savunan Mâtürîdîler, bu bağlamda muhtelif delillere başvurmuşlardır. Çoğu bizzat İmam Mâtürîdî tarafindan ortaya konulan ilgili deliller, temel itibariyle Allah'ın hakîm olmasına, buna bağlı olarak da hikmetsizlik barındıran küfrün affinın, O'nun tarafindan gerçekleștirilmeyeceği anlayışı üzerine bina edilmiştir. Meselenin ayrıntısına inildiğinde ise, küfrün hiçbir hayır barındırmaması, ebedi bir inanç pozisyonunda bulunması, özü itibariyle kabih olup yasağının kalkmasının düşünülememesi, bağışlanmasının uygun bir af konumunda olmaması ve söz konusu affin iyi ile kötüyü eşit bir konuma getirecek olması gibi gerekçelere dayanılmıştır.

* Assoc. Prof., University of Tokat Gaziosmanpaşa Faculty of Islamic Sciences, Department of Basic Islamic Sciences, Branch of Kalam, Tokat, Turkey.

Doç. Dr., Tokat Gazi Osmanpaşa Üniversitesi, İslami İlimler Fakültesi, Temel İslam Bilimleri Bölümü, Kelam Anabilim Dall, Tokat, Türkiye.

İbrahim.bayram@gopl.edu.tr

Type / Türü: Research Article / Araştırma Makalesi

Received / Geliş Tarihi: 5 September / 5 Eylül 2021

Accepted / Kabul Tarihi: 9 November / 9 Kasım 2021

Published / Yayın Tarihi: 28 January / 28 Ocak 2022

Volume / Cilt: 9; Issue / Sayı: 17; Pages / Sayfa: -153-173

Suggested ISNAD Citation: İbrahim Bayram, "Mâtürîyye'de Küfrün Affının Aklen Cevazı Meselesi", Kafkas Üniversitesi İlahiyat Fakültesi Dergisi, 9/17 (Ocak-January 2022), 153-173.

www.dergipark.org.tr 
Anahtar Kelimeler: Kelâm, Mâtürîdiyye, Küfür, Af, Aklî İmkân.

\section{GíRiș}

İnsanlığın dünya ve ahiret saadeti için gönderilen İslâm, bu mutluluğa ulaşmaları için onlardan çeşitli isteklerde bulunmuş, bu isteklere karşı takındıkları tutuma bağlı olarak onları mümin ve kâfir şeklinde kategorize etmiștir. İslâm, getirdiği hususlara inananlara müjde/va'd, bunları inkâr edenlere ise ikaz/vaîdde bulunmuştur. İlgili naslarda açıkça beyan edilen bu vaîdlerin hakikatine dair herhangi bir şüphe yoksa da bunların uygulamaya sokulmama ihtimali, ilim ehlini meşgul etmiştir.

İslâm uleması genel anlamda şerî̀ naslardan hareketle küfrün affının olmadığı hususunda fikir birliği içindeyken, küfrün aklen bağıșlanma imkânı konusunda görüş ayrılığına düşmüşlerdir. Bu noktada genel çerçeve içerisinde Eş'arîler küfrün aklen affedilme ihtimalini kabul ederken, Mâtürîdîler ve Mu'tezile ise (bu ikinci mezhebe farklı görüşler isnat edilse de) bu ihtimali reddetmişlerdir. Va'd ve vaîd konusunda katı bir tutum benimseyen Mu'tezile'nin böyle bir fikri savunması doğru/doğal gözükmektedir. Bu noktada daha çarpıcı olan ise Mâtürîdiyye mezhebinin de kâfirlerin aklen af ihtimalini reddetmiş olmasıdır.

Mezheplerin konuyla ilgili temel ittifak ve ihtilaf noktalarını Sa'düddîn et-Teftâzânî (öl. 792/1390), daha kapsamlı şekilde aktarmaktadır. Buna göre İslâm ümmeti, küçük günahların mutlak surette, büyük günahların tövbe sonrası affedileceği, küfrün ise şer'î manada bir affa konu olmayacağı hususunda ittifak etmiștir. Küfrün affının aklî yönden cevazı ile tövbe edilmeyen büyük günahın affında ise ihtilafa düşmüştür. Bu son konuda Ehli sünnet, mezkûr affın cevazına; Mu'tezile ise șer'î manada imkânsızlığına, aklî anlamda ise çoğunluk itibariyle imkânına hükmetmiştir. Teftâzânî, küfrün affının aklen imkânı meselesinde, mensubu olduğu Eş'ariyye adına buna cevaz vermiş, ismini zikretmediği; ancak aktardığı gerekçelerden Mâtürîdîleri kastettiği anlaşılan bir kısım zevatın ise buna karşı çıktığını belirtmiştir. ${ }^{1}$

Kafirlerin affının aklen cevazı meselesinde Eş'ariyye ve Mâtürîdiyye mezheplerinin tutumunda bir kapalılık yoksa da Mu'tezile'nin küfrün affına aklen ihtimal verip vermediği hususu nispeten belirsizdir. Teftâzânî, Mu'tezile'nin çoğunluğunun tövbesiz büyük günahın affına aklen imkân tanıdığını, Ebü'l-Kâsım el-Ka'bî'nin ise (öl. 319/931) bu ihtimale de karşı çıktığını belirtmektedir. Başka bir yerde bu fikri Basra Mu'tezilesi ile Bağdat Mu'tezilesi'nin bir kısmının görüşü şeklinde aktarmaktadır. ${ }^{2} \mathrm{Bu}$ açıklamalardan onların küfrün affına aklen cevaz verdikleri gibi bir husus anlaşılmamaktadır. Yine Ebü'l-Hasen el-Eş'arî (öl. 324/93536) büyük günaha dönük şer'î naslar bir tarafa bırakıldığında, bu günahın affının caiz olup olmayacağı hususunda Mu'tezile'nin bir bölümünün buna cevaz verirken, diğerlerinin karşı çıtığını ifade etmektedir. ${ }^{3}$ Bir diğer Eş'arî âlim İbnü'l-Müneyyir ise (öl. 683/1284) bu hususta oldukça açık bir ifade kullanmaktadır. Bu bağlamda Mu'tezile'nin kafirin affının aklen caiz olmadığını savunduğunu, buna söz konusu durumun hikmete aykırılık teșkil

1 Sa'düddîn Mesûd b. Ömer b. Abdullah Teftâzânî, Şerhu'l-Makâsıd, thk. Abdurrahman Umeyre (Beyrut: Âlemü'l-Kütüb, 2. Baskı, 1419/1989), 5/148-149.

2 Teftâzânî, Şerhu'l-Makâsıd, 148-152.

3 Ebü'l-Hasen el-Eş'arî, Makâlatü'l-İslâmiyyîn ve ihtilâfü'l-musallîn, thk. Muhammed Muhyiddîn Abdülhamid (Kahire: Mektebetü'n-Nehda'l-Mısriyye, 1950), 2/150. 
etmesini gerekçe gösterdiğini belirtmektedir. ${ }^{4}$ Bu noktada Fahreddîn er-Râzî ile (öl. 606/1210) Ebû Hayyân el-Endelüsî ise (öl. 745/1344), Basra Mu'tezilesi'nin küfrün affına aklen cevaz verdikleri gibi anlaşılabilecek bir ifade kullanmaktadırlar. ${ }^{5}$

Konuyla ilgili olarak Kâdî Abdülcebbâr'ın (öl. 415/1025), Bağdat Mu'tezilesi'nin, günahın affını hiçbir şekilde (aklen de) caiz görmemesi fikrine dönük getirdiği eleștirilere bakılacak olursa onun, dolayısıyla da mensubu bulunduğu Basra Mu'tezilesi'nin günahın affına aklen cevaz verdiği anlaşılmaktadır. Nitekim o, ceza hakkının sahibi olan Allah'ın, tıpkı alacaklıda olduğu gibi bu hakkını düşürmesinin aklî imkânına atıf yapmaktadır. ${ }^{6}$ Yine bașka bir yerde aklın șirk dıșındaki günahların affına cevaz verdiğini ifade ile bu ișe daha güçlü șekilde vurguda bulunmaktadır. ${ }^{7}$ Buradan da onların söz konusu affı, küfür/șirk için değil, günah için aklî cevaz boyutuyla gündeme getirdikleri anlaşılmaktadır. Bir diğer Mu'tezilî müellif Ka'bî ise doğrudan bu konuda değilse de onunla bağlantı kurulabilecek şekilde kafirlere dönük vaîdin hangi yoldan bilindiğine dair bilgi paylaşmaktadır. $\mathrm{Bu}$ manada kimilerinin bu azabın akılla bilineceği, haberlerin de bunu teyit ettiği; kimilerinin ise bunun akılla değil, haberle bilindiği görüşünde olduklarını söyler. Ardından bir zata atıfla bu son görüşün, Mu'tezile'nin temel anlayışı olduğunu, sadece Cafer b. Mübeşşir'in ise (öl. 234/848-49) bu noktada hem kâfirlere hem de fasıklara yönelik azabın akılla bilindiği fikrini savunduğunu belirtir. ${ }^{8}$

Genel anlamda konuyla ilgili diğer temel kaynakların kafirin affının aklen cevazı meselesinde Mâtürîdîler ile Mu'tezile'yi aynı görüşün temsilcisi olarak yansıtıp, Eş'arîleri ise bu fikrin tam zıddı bir kutba yerleștirdiklerine bakılacak olursa, ${ }^{9}$ Mu'tezile'nin bir bölümünün aklen affına cevaz verdikleri hususun küfür değil, büyük günah olması daha doğru gözükmektedir. Nitekim buradaki mezkûr ilk iki mezhebin, her ne kadar aralarında bir kısım farklılıklar olsa da hüsün kubuh ile hikmet konusunda Eş'ariyye'ye nispetle daha yakın bir pozisyon alması ve bu iki konunun kâfirin affının aklen cevazı meselesinde temel belirleyici mevkiinde bulunması da bu hususu güçlendirmektedir.

4 Ebü'l-Abbas Nasırüddîn Ahmed b. Muhammed İbnü'l-Müneyyir, el-İntisâffî mâ tedammenehü'l-Keșşâf mine'li'tizâl, tlk. Halil Me'mun Șeyha (Beyrut: Dârü'l-Marife, 3. Basım, 1430/2009), 317.

5 Ebû Abdillah Fahreddîn Muhammed b. Ömer Fahreddîn er-Râzî, Tefsîru'l-Fahri'r-Râzî (Beyrut: Dârü'l-Fikr, 1981), 12/145; Ebû Hayyân Muhammed b. Yûsuf b. Alî b. Yûsuf b. Hayyân Endelüsî, Tefsirü'l-Bahri'l-muhît, Adil Ahmed Abdülmevcûd-Ali Muhammed Muavvız (Beyrut: Dârü'l-Kütübi'l-İlmiyye, 1413/1993), 4/66.

6 Ebü'l-Hasen Abdülcebbâr b. Ahmed Kâdî Abdülcebbâr, Şerhu'l-Usûli'l-hamse, thk. Abdülkerim Osman (Kahire: Mektebetü Vehbe, 3. Basım, 1416/1996), 644-645.

7 Kâdî Abdülcebbâr, Serhu'l-Usûli'l-hamse, 678.

8 Ebü'l-Kâsım Abdullah b. Ahmed b. Mahmûd el-Belhî el-Ka'bî, Kitâbü'l-Makâlât ve meahû uyûnü'l-mesâil ve'lcevâbât, thk. Hüseyin Hansu-Racih Kürdi-Abdülhamid Kürdi (İstanbul: İstanbul 29 Mayıs Üniversitesi Kur'an Araştırmaları Merkezi (KURAMER); Amman: Dârü'l-Feth, 1439/2018), 395-396.

9 Kemâleddin Muhammed b. Abdülvahid b. Abdülhamid İbnü'l-Hümâm, el-Müsâyere fì ilmi'l-kelâm (Kahire: elMektebetü'l-Mahmûdiyyeti't-Ticâriyye, 1348/1929), 114-115; Ebü'l-Feyz Murtaza Muhammed b. Muhammed b. Muhammed Zebîdî, Kitâbu İthâfü's-sadeti'l-muttakîn bi-şerhi esrâr-ı İhyâi ulûmi'd-dîn (Beyrut: Müessesetü't-Târîhi'l-Arabî, 1414/1994), 2/186; Abdullah b. Osman b. Musa Efendi Mestçizâde, elMesâlik fi'l-hilafiyyât beyne'l-mütekellimîn ve'l-hükemâ, thk. Seyyid Bagcevan (Beyrut: Dâru Sâdır; İstanbul: Mektebetü'l-İ́rşâd, 1428/2007), 156. Bu noktada Said Fûde bir ikazda bulunur. Bu meyanda işbu meselede kimi zevatın mezkûr Mâtürîdî düşünceyi Mu'tezilî anlayıș ile aynı görmelerinin izaha muhtaç olduğunu, bu hususta ilgili iki mezhebin hüsün-kubuh konusundaki fikirlerinin gözden rrak edilmemesi gerektiğine dikkat çeker. Said Abdüllatif Fûde, "Șerh", Mesâilü'l-ihtilâf beyne'l-Eşâ'ire ve'l-Mâtürîdiyye, thk. Said Abdüllatif Fûde (Amman: Dârü'l-Feth, 1430/2009), 62. 
İhsas edildiği üzere bu konuda itikadi fırkaların aldıkları tavrın diğer kimi kelami mevzularda savundukları görüşlerle yakın bir bağı bulunmaktadır. Burada konu ile en yakın ilișkisi olan meselelerin bașında hüsün ve kubuh mevzuu gelmektedir. İyi ve kötünün tamamen Allah'ın tayiniyle tespit edileceğini söyleyen, bu doğrultuda Allah her ne yaparsa onu iyi görüp, burada aklî bir tayine yer vermeyen Eş'ariyye'nin, Allah'ı daha önce haberini verdiği hususlar da dâhil olmak üzere (aklî manada) herhangi bir kayıtla sinırlamaması, onları kâfirlerin affını -șer'î boyutta değilse de- aklen imkânsız görmemeye sevk etmiștir. Buna karşın bazı şeylerdeki hüsün ve kubuhun aklî olduğunu savunan, aklı vacip koyucu pozisyonuna getirmese de onu vacibin bilinmesinde vasita konumunda gören Mâtürîdiyye'nin de mutlak anlamda kötülük içerdiğini söyleyeceği küfrün affını aklî imkân açısından reddetmesi onlar adına tutarlı bir görüștür. Bu konuda fiillerin özü itibariyle hüsün ve kubuh vasfına sahip olduğunu iddia ettiği gibi ayrıca akla vücûbiyet misyonu da yükleyen Mu'tezile'nin de açlk bir şekilde kötü olduğunu düşündüğü küfrün affa tabi olmasını aklen imkânsız görmesi gayet anlaşılabilir bir husustur.

Kâfirin affedilmesinin aklen mümkün olması konusunda farklı tavır alınmasının, ilahi vaîdden dönülmesinin imkânı meselesindeki görüş ayrılıklarıyla da bir ilişkisi vardır. Bilindiği üzere kâfirin azabına dönük ilahi hitaplar, vaîd bildirmektedir. Bu noktada Mâtürîdiye, vaîdden dönmeyi imkânsız görürken, Eş'ariyye'nin bunu bir noksanlık olarak algılamayıp bu işe imkân tanıması,10 onların kâfirin affına bakış açılarını etkilemiş; bu çerçevede ilk mezhep, bağışlanmayı, muhaliyet/imkansızlık içeren vaîdden dönme olarak gördügü için bu duruma sebebiyet veren mezkûr işi olanaksız saymıștır. Buna karşın Eş'ariyye ise doğal olarak bu affı imkânsız görmemiş, ona en azından aklî açıdan bir imkân kapısı aralamıştır.

Gelinen noktada yapılması gereken iş, tarafların bu konuda kendi düşüncelerini nasıl temellendirdiklerini geniş şekilde ortaya koymak ve bunun üzerinden bazı değerlendirmelerde bulunmaktır. Bu çalışmada ise, hususi olarak Mâtürîdiyye'nin ilgili anlayışının gerekçelerinin sunulması ve yeri geldiğinde bunların bir kritiğinin yapılması hedeflenmektedir. Bu iş yapılırken özelikle Ebû Mansûr el-Mâtürîdî'nin (öl. 333/944) görüşlerine, peşi sıra sonraki ulemanın bunlara yönelik yapmış olduğu katkılara başvurulacaktır. Kaynaklar ağırlıklı olarak Mâtürîdî ulemanın eserlerinden seçilecek, buna kimi zaman bir kısım Eş'arî ilim ehlinin telifleri de eşlik edecektir.

Kâfirin affının aklen imkânı meselesi, vurgulandığı üzere Ehl-i sünnet'in iki ekolü arasındaki ihtilaf noktalarından birini teşkil ettiği için, bu iki fırka arasındaki farklılıkları inceleyen Türkçe çalışmalarda mezkûr konuya değinilmişse de, doğal olarak ilgili izahat, ${ }^{11}$ bu makalede yer verilecek açıklamalar kadar yoğun olmamıştır. Yine söz konusu eserlerde her iki mezhebin yaklaşımı benzer bir yoğunlukta kendisine yer bulurken bu çalışmada ise Mâtürîdî anlayışa ağırlık verilmiştir. Bu manada çalışmanın, bir boşluğu dolduracağı ümit edilmektedir.

Konuyla ilgili olarak Mâtürîdî düşüncenin açılımı belirtildiği üzere geniş şekilde işleneceği, bu hususta Mu'tezile de meseleye onlar gibi yaklaştığı için burada farklı görüş bildiren Eş'ariyye'nin anlayışını kısaca incelemek uygun olacaktır. Kâfirlerin affının aklen

10 Abdürrahim b. Ali Şeyhzâde, Nazmu'l-ferâid ve cem 'u'l-fevâid (Kahire: Matbaatü'l-Edebiyye, 1317/1899), 29.

11 Emrullah Yüksel, Mâtürîdîler ile Eș'arîler Arasındaki Görüş Ayrılıkları (İstanbul: Düşün Yayıncılık, 2012), 134138; Mustafa Özgen, Eş'arî ve Mâtürîdî Mezhepleri Arasındaki Görüş Farkları (Konya: Palet Yayınları, 2017), 153157. 
caiz olduğu görüşünü savunan Eş'ariyye, bu hususu kimi zaman mutlak şekilde ifade ile yetinirken, kimi zaman ise buna kanıt mahiyetinde değerlendirilebilecek açıklamalar getirmektedir.

Eş'ariyye'nin önemli kelamcılarından olan Fahreddîn er-Râzî, kâfirlerin affının aklen caiz olduğu görüşünü temellendirirken, mülkün O'na ait olmasına, kimsenin O'na itiraz hakkı bulunmamasına atıf yapmaktadır. ${ }^{12} \mathrm{Bu}$ hususta Teftâzânî ise mensubu bulunduğu Eş'ariyye uleması ve kelamcıların çoğunluğunun küfre dönük bu affı "(șer'an) vaki olmayacak caiz" şeklinde gördüklerini belirtmektedir. ${ }^{13}$ Böylece o, işin pratik kısmında bir ihtilaf yoksa da, teori kısmında kendilerinin küfrün affını caiz gördüklerini söylemiș olmaktadır.

Şüphesiz küfrün affının aklen imkanı konusunda Eş'ariyye'nin temel gerekçelerinin başında Hz. Îsâ'nın, kendisini ve annesini ilah addeden Hıristiyanlarla ilgili "Eğer onlara azap edersen, şüphe yok ki onlar senin kullarındır. Eğer onları bağışlarsan, yine şüphe yok ki sen mutlak güç sahibisin, hüküm ve hikmet sahibisin"14 ayeti gelmektedir. Bu manada örneğin Kâdî Beyzâvî (öl. 685/1286), işbu ayetin tefsirinde kâfirlerin affının aklen caiz olduğunu ihsas etmektedir. Bu manada Hz. Îsâ'nın ilk cümlesini açıklarken; mülkünde yaptığı tasarrufta mutlak malik olan Allah'ın, bu mülkün altına giren kullarına dönük azabının elbette mümkün olduğunu, buna bir itiraz getirilemeyeceğini belirtir. Bu ifadede, o azaba uğrayacak kulların Allah'tan başkasına ibadet etmeleri itibariyle azaba müstahak olduklarına dönük bir tembih bulunduğunu söyler. Hz. Îsâ'nın ikinci cümlesini yorumlarken de; sevap vermeye ve azap etmeye kadir olan Allah'ta herhangi bir acziyet yahut (yaptığ işte) bir kubhiyet bulunmayacağı, O'nun sevabı da cezayı da bir hikmet üzere vereceği ifadelerini kullanır. Peşi sıra her suçluya dönük mağfiretin güzel olduğunu, buna karşın O'nun, başkasını ilah edinenlere dönük azabının adalet, affının ise bir lütuf olduğunu ifade eder. Burada şirkin, ilgili vaîd çerçevesinde bağışlanmamasından, ${ }^{15}$ onun (kâfirin affının) özünde muhaliyet barındırdığı yorumunun çıkarılamayacağını kaydeder. ${ }^{16}$

Beyzâvî, bu af ihtimalini bir başka eserinde çok açık bir şekilde vurgular. $\mathrm{Bu}$ meyanda doğru yola ulaşmak için yoğun şekilde gayret gösteren kâfirin affının, ilahi bir lütuf neticesi mümkün olabileceğini belirtir. Bu kişiyi, daha çok inatçı kâfir konumunda bulunmayan kimse şeklinde takdim ederek, arayış halindeki kâfirin affına (aklî imkân boyutuyla) bir kapı açar. ${ }^{17}$

Eş'arî âlim İbnü'l-Müneyyir de mezkûr ayetin izahında hem mensubu bulunduğu mezhebin kâfirin affına bakışını açıklar hem de söz konusu ilahi kelamdan yaptığı istidlali ortaya koyar. Eş'arîleri kastederek Ehl-i sünnet'in şer'î planda ebedi azaba uğratılacağı belli olan kâfirin affını, hatta takva ehli bir zatın tazibini aklen caiz gördügüünü söyler. İlgili ayetlerin, aksi ihtimalin (kâfirin affı) aklen cevazına engel teșkil etmediğini belirtir. Söz konusu ayette (Mâide 5/118) geçen ve eklendiği fiilin gerçekleşmesine ihtimal tanıyan "in" edatının kullanım şeklinin de aksi görüşe zıt olup bunun kendi fikirlerini teyit ettiğini söyler.

12 Fahreddîn er-Râzî, Tefsîru'l-Fahri'r-Râzî, 12/144.

13 Teftâzânî, Șerhu'l-Makâsıd, 5/151.

14 el-Mâide 5/118.

15 en-Nisâ $4 / 48$.

16 Ebû Saîd Nâsırüddîn Abdullah b. Ömer b. Muhammed Beyzâvî, Envârü't-tenzîl ve esrarü't-te'vîl, thk. Muhammed Abdurrahman el-Maraşlı (Beyrut: Dâru İhyâi't-Türâsi'l-Arabî, ts.), 2/151.

17 Ebû Saîd Nâsırüddîn Abdullah b. Ömer b. Muhammed Beyzâvî, Tavâli'u'l-envâr min metâli'i'l-enzâr, thk. Abbas Süleyman (Beyrut: Dârü'l-Cîl; Kahire: el-Mektebetü'l-Ezheriyye li’t-Türâs, 1411/1991), 228-229. 
Bunu da dâhil olduğu fiilin şüphe/ihtimal bildirdiğini gösteren "in" edatının aklen imkânsız olan bir fiilin bașına gelemeyecek olması ile izah eder. ${ }^{18}$ Böylece o kâfirlerin affedilme durumunu bildiren fiilin bașına bu edatın dâhil olmasından hareketle işbu affın bir ihtimal barındırdığını ifade etmiş olur.

Küfrün affının aklen imkanı meselesi Mâtürîdîler ile Eş'arîler arasındaki temel ayrılık noktalarından birini teşkil ettiği için bazen tarafların yaklaşım ve gerekçeleri, muhalif ekolün bir mensubu tarafından da açıklanır. Nûreddîn es-Sâbûnî (öl. 580/1184) ile Ebü'l-Berekât en-Nesefî (öl. 710/1310), Eş'arî mezhebinin konuyla ilgili görüşünü aktarırken bu durumun bir örneğini vermektedir. Bu manada onlar, Eș'arîlerin küfür ve şirkin affının aklen caiz olduğu fikrini benimsediğini belirtirler. Bu noktada her iki zat da çarpıcı şekilde bu görüşe ilave olarak onların, müminlerin cehennemde, kâfirlerin cennette ebedi kalmalarına aklî çerçevede cevaz verdiklerini de ilave ederler. Böylece onlar sanki ortaya çıkan sonuç üzerinden ilgili Eş'arî görüşün zafiyetini daha güçlü şekilde vurgulamak isterler. Ancak her iki müellif de, hemen ardından meselenin özünü zikrederek onların, șer'î anlamda bu ihtimalleri reddettiklerini belirtirler. ${ }^{19}$ Yine Eş'arîler'in kâfirin affına aklî boyut itibariyle imkân tanırken bunu; Allah'ın, mülkünde dilediği gibi tasarruf edebileceği, böyle bir işin zulüm olmayacağı, zira zulmün, başkasının mülkünde tasarruf olduğu yönünde bir izah geliştirdiklerini,20 ayrıca bunda herhangi bir şekilde sefehlikten de bahsedilemeyeceğini ileri sürdüklerini kaydeder.21

Mestçizâde Abdullah Efendi de (öl. 1150/1737) Eş'arîlerin küfür ve şirkin affını aklen caiz gördüklerini, onlara Allah'ın şirki affetmeyeceğine dönük ayeti hatırlatıldığında, buna onun şer'î bir gereklilik bildirdiği, aklî planda böyle bir zorunluluk bulunmadığı şeklinde karşılık verdiklerini söyler.22 Ebû Azbe ise (öl. 1172/1759) bu konudaki ihtilafı, kâfirin aklen affı ile aynı pozisyonda bulunan itaatkâra dönük azabın cevazı meselesi üzerinden sunar. Eș'arî̀nin bu işe aklen imkân tanırken Ebû Hanife'nin/Mâtürîdîlerin ise buna ne aklen ne de şer'an cevaz verdiklerini söyler. ${ }^{23}$

\section{Mâtürîdîlerin Kâfirin Affının Aklen Cevazına Yaklașımı}

Eş'ariyye ile Mâtürîdiyye mezheplerinin ayrılık noktalarından biri olarak gösterilen kâfirin affının aklen cevaziyeti meselesinde, ${ }^{24}$ özellikle İmam Mâtürîdî, bu işin caiz olmadığı meyanında hususi şekilde kanıtlar getirmiş, sonraki Mâtürîdî ulema da ilgili delilleri teyit etmiştir. Burada Mâtürîdî ulema, genel anlamda aynı fikrin savunuculuğunu yapmış, ancak mezhebinin eğilimine uymayan zatlar da ortaya çıkmıştır. Bu manada örneğin Nûreddîn esSâbûnî, Mâtürîdî anlayış doğrultusunda küfrün aklen cevazının söz konusu olmadığını

18 İbnü'l-Müneyyir, el-Intisâf, 317.

19 Ebû Muhammed Nuruddîn es-Sâbûnî, Kitâbü'l-Bidâye mine'l-kifâye fi'l-hidâye fi usûli'd-dîn, thk. Fethullah Huleyf (Kahire: Dârü'l-Maârif, 1969), 145; Ebû Muhammed Nuruddîn es-Sâbûnî, el-Kifâye fi'l-hidâye, thk. Muhammed Arûçî (Beyrut: Dârü İbn Hazm; İstanbul: Türkiye Diyanet Vakfı İslam Araştırmaları Merkezi (ISAM), 1435/2014), 336; Ebü'l-Berekât Hâfızüddîn Abdullah b. Ahmed b. Mahmûd en-Nesefî, Şerhu'l-'Umde fî akîdeti Ehli's-sünne ve'l-cemâa', thk. Abdullah Muhammed Abdullah İsmail (Kahire: el-Mektebetü'lEzheriyye li't-Türâs, 2011), 422.

20 Sâbûnî, el-Kifâye fi'l-hidâye, 336; Ebü'l-Berekât en-Nesefî, Şerhu'l-'Umde, 422.

21 Sâbûnî, Kitâbü'l-Bidâye, 145.

22 Mestçizâde, el-Mesâlik fi'l-hilâfiyyat, 49, 121.

23 Hasen b. Abdülmuhsin Ebû Azbe, er-Ravzatü'l-behiyye fî mâ beyne'l-Eşấire ve'l-Mâtürîdiyye (Haydarabad: Dâiretü'l-Maârifi'n-Nizamiyye, 1322), 32.

24 İbn Kemal Ahmed Şemseddin Kemalpaşazâde, Mesâilü'l-ihtilâf beyne'l-Eşâire ve'l-Mâtürîdiyye, thk. Said Abdüllatif Fûde (Amman: Dârü'l-Feth, 1430/2009), 59; Şeyhzâde, Nazmu'l-ferâid, 30-31. 
belirtmiş,,25 Hanefi fakihi Şemsüddîn et-Timurtâşî de (öl. 1006/1598) aynı hususu teyit etmişken,26 İbnü'l-Hümâm (öl. 861/1457) gibi Mâtürîdî bir zat ise bu hususta Eş'arî görüşü benimsemiştir. ${ }^{27}$

İmam Mâtürîdî, kâfirin herhangi bir șekilde affının caiz olmadığını savunurken bunu, daha çok kâfiri, günahkâr müminle mukayese ederek ortaya koymaktadır. Bunu da Mu'tezile mezhebine eleştiri mahiyetinde dile getirmektedir. Bu noktada ilgili izahatı bütün teferruatıyla bir mukayese çerçevesinde aktarmak konuyu uzatacağı için burada mümkün mertebe ağırlıklı olarak şirk/küfür üzerinden dile getirdiği hususlara değinmek, karşılaştırma yapıldığında ise bunun diğer günahlarla ilgili olan kısmını muhtasar şekilde aktarmak daha uygun olacaktır.

Bu mukayeseli izah biçimi sonraki Mâtürîdî ulema tarafından da devam ettirilir. $\mathrm{Bu}$ manada örneğin Ebü'l-Muîn en-Nesefî (öl. 508/1115) konuyla ilgili bilgi aktarırken İmam Mâtürîdî gibi genel anlamda küfür ile diğer günahların aynı şekilde cezalandırılamayacağını beyan etmeyi hedefler. Burada onun asıl amacı, günahın affını (şer'an) caiz görmeyen Mu'tezile'yi eleştirmek ise de o, işin içerisine Eş'arîleri de katar. Sitemkâr bir ifadeyle söze başlayan müellif, kâfirlerin affına (aklen) cevaz veren kelamcıların (Eş'arîler) aslında küfür ile diğer günahlar arasında affın cevazı ve ebedi azabı gerektirip gerektirmemesi bağlamında bir mukayese yapma ihtiyaçları bulunmadığını söyler. ${ }^{28}$

Görülebildiği kadarıyla İmam Mâtürîdî, kelam eserinde açık bir şekilde küfrün affının aklen caiz olmadığını ifade etmez; ancak bu şekilde yorumlanabilecek kimi izahlar getirirken, tefsirinde ise tam bir sarahatle şirkin affının aklen caiz olmadığını belirtir. ${ }^{29}$ Mâtürîdiyye mezhebinin sistemleștiricisi olarak gösterilen Ebü'l-Muîn en-Nesefî de bu hususta İmam'ın kelam eserindeki izah biçimini benimser. Nûreddîn es-Sâbûnî ve Ebü'lBerekât en-Nesefî gibi sonraki Mâtürîdî ulema ise meseleyi küfrün/şirkin affının aklen caiz olmayacağı şeklinde aktarırlar. Onlar konuyu bu açıklıkta ifade ederken, ya İmam'ın kelam eserinden böyle bir netice çıkarmıș veya tefsir eserinden esinlenmiş yahut da her iki durumu birden itibara almış olmalıdırlar.

Sâbûnî ve Ebü'l-Berekât en-Nesefí'nin burada konuyu sunuş biçimi sonrasında aynı şekilde devam ettirilir. Bu meyanda çoğu ilim ehli ilgili maddeleri, "küfrün affının aklen caiz olmaması" görüşünün kanıtları mahiyetinde aktarır. Nitekim hilaf türü eserlerde meselenin bu şekilde nakledildiği görülür. Yine İbn Kemâl'in (öl. 940/1534) hilaf eserini tahkik ve șerh eden Said Fûde de, aynı şekilde ilgili maddelerden hareketle mezkûr durumun aklî zorunluluk bildirdiği şeklinde değerlendirilmesinin mümkün olduğunu belirtir. ${ }^{30}$ Bütün bu ifade biçimleri artık konunun belirli bir şablon üzerine oturduğuna işaret etmektedir.

25 Sâbûnî, Kitâbü'l-Bidâye, 145.

26 Şemseddîn Muhammed b. Abdullah b. Ahmed el-Gazzî et-Timurtâşî, Muînü'l-müftî ala cevâbi'l-müsteftî, thk. Mahmud Șemseddin Emir el-Hazzai (Beyrut: Darü'l-Beșairi'l-İslamiyye, 1430/2009), 43.

27 İbnü'l-Hümâm, el-Müsâyere, 114.

28 Ebü'l-Muîn Meymûn b. Muhammed b. Muhammed en-Nesefî, Tebsiratü'l-edille fî usûli'd-dîn, thk. Muhammed Enver Hamid Îsâ (Kahire: el-Mektebetü'l-Ezheriyye li't-Türas, 1432/2011), 2/1064.

29 Ebû Mansûr Muhammed b. Muhammed b. Mahmûd Mâtürîdî Semerkandî Mâtürîdî, Te'vîlâtü'l-Kur'an, thk. Mehmet Boynukalın (İstanbul: Mîzân Yayınevi, 2005), 3/257.

30 Said Abdüllatif Fûde, "Şerh”, 62. 


\subsection{Mâtürîdiyye'de Küfrün Affının Aklen Caiz Olmamasının Gerekçeleri}

Mâtürîdiyye mezhebinin konuyla ilgili zikrettiği gerekçelerin neredeyse tamamı İmam Mâtürîdî'nin izahatına dayanmaktadır. Bu gerekçeler işbu fikre katılsın yahut karşı çıksın adeta bütün ilim ehlinin kâfirin affının caiz olmaması meyanında saydığı temel maddeler konumunu ihraz etmektedir. Bu maddeler zikredilirken kimi zaman İmam Mâtürîdî̀nin ismine kimi zaman diğer Mâtürîdî kelamcıların, özelikle Umde sahibi şeklinde Ebü'l-Berekât en-Nesefínin adına atıf yapılmakta, bazen mutlak surette söz konusu gerekçelerin zikriyle yetinilmektedir. Bu noktada kaynaklar özellikle Ebü'l-Berekât enNesefî ismine atıf yapsa da, görüldügü kadarıyla meselenin izahında onun daha çok Sâbûnî'ye dayandığı kaydedilmelidir.

Sözü edilecek gerekçelerin hepsi bir maddede toplanmak yahut onların ana noktası vurgulanmak istense, herhalde kullanılacak temel kavram "hikmet" olacaktır. Allah'ın abes yahut sefeh gibi durumlardan tenzihini bildiren hikmeti O'nun fiillerinde, Mu'tezile gibi bir vücûb șeklinde değilse de, ayrılmaz bir parça olarak gören Mâtürîdî anlayıș, küfrün affının söz konusu hikmeti zedeleyeceğini belki de ortadan kaldıracağını, bunun ise Allah'ı münezzeh olduğu bir husus ile nitelendirme anlamına geleceğini savunmaktadır. Bu yüzden ilgili gerekçelerde kimi zaman hikmet kavramı doğrudan kullanılarak, bazen onun içerdiği mana ortaya konularak, ona temel bir fonksiyon yüklenmiștir. Bu konuda Mâtürîdiyye'yi Mu'tezile ile birleştirip onu Eş'ariyye'den ayıran temel maddelerden biri de işte bu anlayış olmuştur. İlk iki mezhep, hikmeti, genel anlamda özellikle hüsün ve kubuhluğu bilinen durumlarla ilgili önceden belirli bir konumda görürken, diğer mezhebin bunu, mutlak şekilde herhangi bir olmuş yahut olası ilahi fiilin neticesi olarak değerlendirmesi, mezkûr konuda ittifak ve ihtilafların ana sebebini teşkil etmiştir.

Burada belki bütün kelami konularda; Mâtürîdiyye'nin ilahi hikmeti, Eş'ariyye'nin ise ilahi iradeyi önceleyen bir tavır benimsemesinin mezkûr meselenin izahına güçlü bir şekilde yansıdığını ifade etmek de mümkündür. Açıkçası, ilkini benimseyenin ikincisinde, ikinciyi önceleyenin birincisinde taviz vermemesi pek de olası gözükmemektedir. Elbette tarafların böyle bir taviz niyeti olmayıp, iş tamamen Allah'ın tenzihi meselesi üzerine temerküz etse de, ortaya çıkan sonucun, her iki görüş adına da kısmi sıkıntılar ihtiva ettiği, hakikat olsa gerektir.

Mâtürîdiler, konuyla ilgili tavır alırken mezhebi önceliklerine uygun olarak kâfirin affını aklen de caiz görmemiş, bunun için çeşitli gerekçelere tutunmuşlardır. Şimdi, küfrün hiçbir hayır barındırmaması, küfür için bir had cezasının bulunmaması, küfrün ebedi bir inanç pozisyonunda olması, küfrün özü itibariyle kabih olup, haramlığının kalkmayacak olması, küfrün affının, uygun bir af konumunda olmayacağı, küfrün affının iyilik yapan ile kötülük işleyeni eşit hale getireceği şeklindeki gerekçeleri, daha çok İmam Mâtürîdî'nin işbu sıralaması üzerinden aktarmak uygun olacaktır.

\subsubsection{Küfrün Hiçbir Hayır Barındırmaması}

Mâtürîdî konuya giriş sadedinde önce meseleye nasıl bakacağının ipucu mahiyetinde bir izah geliştirir. Bu manada Allah'ın, günahlara misliyle karşıllı vereceğini bildirdiğini, bu noktada işin şer î kısmı bir tarafa, azap etmenin/tazibin de istenilene istendiği gibi uygulanan bir fiil değil, bir hikmet çerçevesinde yürürlüğe konulacak bir hal olduğunu belirtir. Peşi sıra günahkârdan farklı olarak şirk/küfür üzere bulunan kişinin bir hayır ve hasene vasfına layık olacak bir pozisyonu olmadığını söyler. Bunu da; kâfirin 
Allah'ın emir ve yasağını inkâr edip yalanlaması ile açıklar. Bu durumda kâfir için bir af umudu bulunmayacağını, onun azabının sürekli olmasında da, kerem ve cömertliğe aykırı bir halden bahsedilemeyeceğini kaydeder. ${ }^{31}$

Mâtürîdı̂’nin yukarıdaki izahı, Ebü'l-Muîn en-Nesefî tarafından da sürdürülür. Bu anlamda o, büyük günah sahibinin, hevasına uyma, öfkesine kapılma gibi durumlara mebni isyana düşse de ilahi azaptan korkma, ilahi rahmeti umma, Allah'ın keremine güvenme gibi çeșitli hayırları da haiz olduğunu, bu noktada onun hayırlarının gereğinden mahrum bırakılıp da, kötülüğünün cezasının kendisine kesilmesinin mümkün olmadığını belirtir. Hemen burada ilgili hususlarda kâfirin pozisyonunu değerlendiren müellif, onun Allah'ı yalanlamasına, ilahi emir ve yasağı inkâr etmesine mebni işbu hayırların hiçbirisini taşımadığını söyler. Böylece onun affının neden caiz olmadığını göstermiş olur. ${ }^{32}$ Müellif, bir başka vesileyle yine şer işlese dahi, azap korkusu ve af ümidi gibi ibadet pozisyonunda olan birtakım halleri taşıyan, ayrıca kimi hayırlı amelleri de bulunan kişinin hayrının görmezden gelinip, şerrine ceza verilmesinin, iyiliğe on, kötülüğe bir katı bedel verileceği ifadelerini çelişkili hale getireceğini kaydeder. ${ }^{33}$

Yukarıdaki açıklamaların vurguladığı kimi hususlar, nispeten farklı bağlamda da olsa Ebü'l-Yüsr el-Pezdevî (öl. 493/1100) tarafından da teyit edilir. Bu meyanda müellif, günahkârın neden ebedi azaba duçar olmayacağı hususunu açıklarken, bu kişinin bir günaha bulaştı̆̆ı için, sahip olduğu iman ile taatleri ve diğer kimi günahlardan kaçınma durumunun tamamen devre dışı bırakılmasının muhaliyet içerdiğini belirtir. ${ }^{34}$

Mâtürîdînin kâfirlerin affedilmeyecekleri hususunu temellendirirken sıklıkla hikmete atıf yaptığı görülür. Yine bunlardan birinde aklen bütün günahlardan daha ağır bir eylem olan şirkin, ayrıca diğer günahlardan farklı olarak sahibine bir hasene yazılmasını engellediği hesaba katıldığında onun cezasının ebedi azap olması gerektiği hususunun ortaya çıktığını söyler. Bu noktada suçuna göre ceza vereceğini bildiren Allah'ın, şirki diğer günahlarla aynı kefeye koyması, üstelik ilkinin yanına hiçbir hasene eklenmesi mümkün olmayıp, diğerinin bu imkâna sahip bulunuyorken bunu yapmasının, hikmete aykırı olacağını belirtir. ${ }^{35}$ Böylece şirk ve küfür gibi suçların ebedi azap ile cezalandırılmasının bir hikmet gereği olduğunu zikretmiş olur.

Muhtasar kelam eseri olan el-Bidâye'de kâfirin affının caiz olmamasını daha çok küfrün içerdiği kötülükler üzerinden aktarırken, daha geniş muhtevada kaleme aldığı elKifâye eserinde küfrün çirkinliğini, kimi zaman diğer günahlarla mukayese yaparak aktaran Sâbûnî de benzer muhtevada bir açıklama getirir. Bu manada imanla birleşmeyen, buna bağlı olarak da bir haseneye ulaşma imkânı barındırmayan küfre karşılık; en değerli hasene olan imanı bünyesinde taşıyan günahkârın ebedi azaba duçar olmasının, o en değerli

31 Ebû Mansûr Muhammed b. Muhammed b. Mahmûd el-Mâtürîdî, Kitâbü't-Tevhîd, thk. Bekir TopaloğluMuhammed Arûçî (Beyrut: Dâru Sâdır; İstanbul: Mektebetü'l-İrşad, ts.), 457-458.

32 Ebü'l-Muîn en-Nesefî, Tebsiratü'l-edille, 2/1064-1065.

33 Ebü'l-Muîn Meymûn b. Muhammed en-Nesefî, Kitabü't-temhîd li kavâidi't-tevhîd, thk. Habîbullah Hasan Ahmed (Kahire: Dârü't-Tıbâati'l-Muhammediyye, 1986), 366.

34 Ebü'l-Yüsr Muhammed b. Muhammed b. Hüseyin el-Pezdevî, Usûlü'd-dîn, thk. Hans Peter Linss (Kahire: elMektebetü'l-Ezheriyye li't-Türas, 1424/2003), 139.

35 Mâtürîdî, Kitâbü't-Tevhîd, 458. 
güzellik olan imanın karşılıksız kalmasına sebebiyet vereceğini, bunun ise hikmete aykırı olacağını belirtir. ${ }^{36}$

Ebü'l-Berekât en-Nesefî, bahsi geçen açıklamaları günahkâr-kâfir mukayesesi üzerinden teyit eder. Bu manada isyan vaktinde dahi Allah'ın azabından korkma, rahmetini umma, keremine güvenme gibi bir kısım hayırlara sahip olan günahkâra, bu hayırlarına karşılık verilmeyip de işlediği şerrin cezasının ödetilmesinin caiz olmadığını belirtir. Buna karşın Allah'ı yalanlayıp O'nun emir ve nehiylerini inkâr etmesi sebebiyle kendisinde hayır namına hiçbir şey barındırmayan kâfirde ise ne bir rahmet umudu, ne azap korkusu ne de ilahi kereme güvenme hissiyatı olduğunu söyler. ${ }^{37}$ Buna bağlı olarak da onun ebedi azaba maruz kalmasının şaşılacak bir durumu olmadığını ima eder.

\subsubsection{Küfür İçin Bir Had Cezasının Bulunmaması}

Mâtürîdî, kâfirin ebedi cezaya müstahak olması gerektiğini, had cezalarından hareketle de ispatlamaya çalışır. Buna göre dünya hayatında uygulanan had cezaları, ilgili günahların keffareti olmaktadır. Eğer bu keffaret fikri doğru olmazsa, günahların cezası küfrün cezasından daha ağır olmuş olur. Böyle bir işin (küfrün cezasının diğer günahlardan hafif olmasının) muhaliyeti, ilgili hadlerin keffaret olduğunu ispatlar. Dünyada küfrün keffaretinin olmaması, onda cezalandırma hususunda bir sınır bulunmadığını gösterir. 0 halde küfrün cezası sınırsız yani ebedi, diğer günahların cezası ise sınırlı olmalıdır. Zaten küfre dönük vaîd haberleri de bu minvalde varit olmuştur. ${ }^{38}$

Mâtürîdî̀nin bu açıklamasında, bir kısım temellere, belki daha doğru bir ifadeyle bazı ön kabullere dayandığı görülmektedir. Bunların başında küfrün cezasının, diğer günahlardan daha hafif olamayacağı ilkesi gelmektedir. Ona göre günahlarda had cezaları bulunuyorken küfürde böyle bir had cezasının olmaması, normalde, günahın cezasının küfürden ağır olmasını gerektirir. Bu ise muhal olduğuna göre onun bu muhaliyetini aşacak şekilde, o cezaları, günahın keffareti kabul etmek gerekir. Böylece o hadler, keffaret olması, dolayısıyla da safi bir cezadan ibaret bulunmaması itibariyle günahın cezası, küfrün cezasını aşmamış olur. Günaha keffaret olan bu hadler, aynı zamanda bu boyutuyla ilgili günahın cezasının sınırlı olduğuna da işarettir. Burada küfürde bir had cezası, dolayısıyla bir keffaretin bulunmaması ise, onun günahına dünyada keffaret olacak bir şeyin olmadığını, kendisinde böyle bir had ve sınır olmayan küfrün ise ancak ebedi azap ile karşılığını bulacağını gösterir.

Görülebildiği kadarıyla bu delil, sonraki Mâtürîdî ulema tarafından kullanılmamıştır. Muhtemelen işbu kanıtın küfrün affının muhaliyetinden ziyade onun cezasının neden ebedi olduğu hususu üzerine yoğunlaştığı için ona bu meyanda atıf yapılmamış olsa gerektir.

\subsubsection{Küfrün Ebedi Bir İnanç Pozisyonunda Olması}

İmam Mâtürîdî küfrün ebedi cezayı gerektirdiği hususunda başka bir delil daha zikreder. Buna göre küfür kendisine bağlanılan bir mezhep/inançtır. Bu türden bir bağlılık sonsuza kadar sürer. 0 halde onun cezasının da böyle ebedi olması gerekir. Buna karşılık diğer günahlar ise her daim bulunmayan, arzuların baskın çıkması anında zuhur eden haller

\footnotetext{
36 Sâbûnî, el-Kifâye fi'l-hidâye, 337.

37 Ebü'l-Berekât en-Nesefî, Șerhu'l-'Umde, 424.

38 Mâtürîdî, Kitâbü't-Tevhîd, 458.
} 
pozisyonundadır. Bu durumda o günahın cezasının da böyle muvakkat olması gerekir. ${ }^{39}$ Mâtürîdî, kelam eserinde getirdiği bu izahı tefsirinde de teyit eder. Bu kez mezhep değil din ifadesini kullanır. Bir inancı benimseyen, onu ebediyyen sürdürürken, günah işleyen kișinin bunu bir anlık arzusuna yenik düșerek yaptığını, sonra da ondan pişmanlık duyduğunu kaydeder. Bunun șirkin neden ebedi azabı gerektirdiğinin bir izahı olduğunu zikreder. ${ }^{40}$

Bu delil, küfür ile diğer günahların birbiriyle mukayesesine bağlı olarak anlaşılması gereken bir kanıttır. Küfrün ebedi, diğerinin ise muvakkat bir pozisyonda olması üzerine kuruludur. Ancak bu noktada mezkûr kanıtın ilk așamada bir kısım itirazlara mahal olabileceği, belki diğer bir ifadeyle onun tartıșmasız bir delil mahiyetinde olmadığı hatıra gelmektedir. Zira şayet, küfür sonsuza kadar süren bir bağlllık ise, bu durumda kâfirlere kitap ve peygamber gönderilmesi bir boyutuyla anlamını yitirmektedir. Gündelik hayatta hem ihtida hem de irtidata rastlanılması, söz konusu delili nispeten tartışmalı hale getirmektedir. Ancak ilgili kanıtta, kişilerin nihai durumu dikkate alınıyor olsa gerektir. $\mathrm{Bu}$ bağlamda kâfir olarak ölen kişinin, belki kiyamete kadar da yaşasa, vaziyetinde bir değişiklik olmayacağı, bu durumda ona da aynı șekilde sonsuz bir ceza uygulanması gerektiği vurgulanmaktadır. Yine bu kanıtta belli ki, anlık bir gafletle muvakkat bir zaman diliminde işlenen günaha karşıllk, küfrün kişinin ömrünün bütün zaman dilimlerini kapsıyor olması göz önüne alınmıştır.

Bu kanıt, diğer Mâtürîdî âlimleri tarafından da kullanılır. Bu manada Ebü’l-Muîn enNesefî arzuların galebe çalması anında gerçekleşen, bu doğrultuda sınırlı bir vakit zarfında vuku bulan ve işleyende tövbe azmi uyandıran bir büyük günaha karşılık, küfrün bir inanç olması itibariyle devamlılık arz ettiğini, bu meyanda ilkinin cezasının muvakkat, ikincisinin devamlı olması gerektiğini belirtir. ${ }^{41}$

Pezdevî, sistemli bir şekilde küfrün affının neden aklî olarak da caiz olmayacağını izah için küfür-günah ayrımına başvurmasa da bir vesileyle günahın, şirkten farklı tarafını beyan için bir açıklama getirir. Bu anlamda günahın, arzuların kişiye galebe çalmasıyla vuku bulduğunu, bunda ilahi emre dönük bilinçli bir muhalefetin olmadığını, ilahi emre uyma, yasaktan kaçınma lüzumuna inanıldığını, Allah'a da tazim edildiğini belirtir. İşbu tazimi ihlal eden müşrikin ise elbette günahkâr müminle aynı durumda bulunamayacağını söyler. ${ }^{42}$ Yine bir vesileyle müminin sonuç itibariyle mutlak anlamda asi olmayacağını, bu durumun kâfir için söz konusu edileceğini, ilgili ikrarı nedeniyle günahkârın özünde itaatkâr konumunda bulunduğunu belirtirken de aynı hususu teyit etmiş olur. ${ }^{43}$ Her ne kadar Pezdevî, bu açıklamalarını günahın geçiciliği, küfrün ebediliği sadedinde yapmasa da ilgili izahatın aynı hususu teyit ettiği açıktır. Bir diğer Mâtürîdî kelamcı Ekmelüddîn el-Babertî de (öl. 786/1384) yine farklı bir bağlamda da olsa, günahkârın, arzusuna mağlup olduğunu, ancak yaptığı işin haramlığına itikat ile ilahi azaptan endişe duyduğunu belirtirken benzer bir vurgu yapmış olmaktadır. ${ }^{44}$

39 Müellif bu noktada diğer günahların ise, özellikle arzuların baskısına bağlı olarak muvakkat bir zaman diliminde işlendiğini, cezasının da ona göre sınırlı bir vakte tahsis edildiğini söyler. Mâtürîdî, Kitâbü't-Tevhîd, 459.

40 Mâtürîdî, Te'vîlâtül-Kur'an, 3/257.

41 Nesefî, Tebsiratüll-edille, 2/1065.

42 Pezdevî, Usûlü'd-dîn, 138-139.

43 Pezdevî, Usûlü'd-dîn, 141.

44 Ebû Abdullah Ekmeleddîn Muhammed b. Muhammed el-Bâbertî, Şerhü'l-Akîdeti't-Tahâvî, tlk. Abdüsselâm b. Abdülhâdî Şennâr ([Beyrut]: Dârü'l-Beyrûtî, 1430/2009), 103. 
Konuyla ilgili olarak Sâbûnî, el-Bidâye eserinde oldukça muhtasar şekilde küfür ebedi bir inanç pozisyonunda olduğu için onun cezasının da ebedi olması gerektiğini söylemekle yetinirken, ${ }^{45}$ el-Kifâye eserinde daha geniș bir açıklama yapar. İșbu mezkûr son eserinde küfrün ebedi inanç pozisyonunda olmasını diğer günahlar ile mukayeseli şekilde aktarırken daha doyurucu bilgiler verir. Buna göre küfür üzere olan kişi, onu sürekli hale getirip, bundan dönme gibi bir azim içerisinde olmayacağı için onun cezası buna uygun olarak ebedi olmalıdır. Günahlarda ise böyle bir devamlılık düşüncesi olmaz. Günah daha çok arzuların benliğe galip gelmesiyle oluşmuş olup kişi o yaptığına tövbe etmesi gerektiğinin bilincindedir. Bu durumda onun cezası da suçunun geçiciliğine uygun olarak sonlu olmalıdır. Bu kiși, lisanen tövbe etmese dahi, bir af ümidi içerisinde cezadan korkar bir konumda bulunur. Allah'ın böyle bir kișiyi affetmesi hikmet olacak iken; itikadını güzel gören, herhangi bir ceza korkusu tașımayan, bunun için bir af talebinde de bulunmayan kâfirin affı ise hikmete aykırılık teşkil edecektir. ${ }^{46} 0$ halde kâfirin affı aklen de caiz değildir.

Ebü'l-Berekât en-Nesefî de arzuların baskın olduğu zaman zarfında, dolayısıyla muayyen bir vakit diliminde işlenen günah ile ebedi bir inanç pozisyonunda olan küfrün karşılıklarının kendi durumlarına göre tespit edileceğini, buna göre ilkine süreli, ikincisine süresiz ceza uygulanacağını kaydeder. ${ }^{47}$

Bir ekol ismi vermeden aktardığı bilgide Teftâzânî de, kafirlerin affının aklen caiz olmadığını savunanların, küfrü bir inanç/mezhep olarak değerlendirip, bu inanca bağlılığın sonsuza kadar sürdüğü gibi bir argüman ürettiklerini söyler. ${ }^{48}$ Bir diğer Eş'arî âlim İbrahim el-Lekânî de (öl. 1041/1632) benzer ifadeler kullanır ve onların nasıl küfür böyle ebedilik arz ediyorsa, cezasının da aynı şekilde sonsuz olması gerektiği yönünde kanıt ortaya koyduklarını belirtir. ${ }^{49}$

\subsubsection{Küfrün Özü İtibariyle Kabih Olup, Haramlığının Kalkmayacak Olması}

Mâtürîdî, kâfirin ebedi cezaya çarptırılması gerektiğini, hüsün kubuh anlayışı üzerinden de ispat etmeye çalışır. Buna göre küfür özü itibariyle kabihtir. Küfür, normal karşılanabilecek, hakkındaki yasak ortadan kalkabilecek bir durum değildir. Hikmet itibariyle küfrün cezasının affedilmesi imkânsızdır. Müellif bu noktada diğer günahların haramiyetinin kalkması ve mübah konuma gelmesinin ise aklen mümkün olduğunu vurgular. Dolayısıyla cezaların da buna uygun olması gerektiğini kaydeder. Bu ifadeleriyle müellif, haramlığı hiçbir zaman kalkmayacak olan bir işe gönül verenlerin, yine bu şekilde, hiçbir zaman azaptan halas olmamaları gerektiğini vurgulamış olur. ${ }^{50}$

Mâtürîdî, bu noktada her daim kötü olmaya ve kalmaya mahkûm olan küfrün cezasının ebediliğini hikmetin gereği olarak sunmak suretiyle aslında kâfirin affının aklen caiz olmadığını da ihsas etmektedir. Zira buna cevaz vermek, onların hikmet anlayışı üzerinden gidildiğinde, aynı zamanda Allah'ın, hikmetsizliğine yahut abes iş yapmasına da

45 Sâbûnî, Kitâbü'l-Bidâye, 146; Sâbûnî, el-Kifâye fi'l-hidâye, 337-338.

46 Sâbûnî, el-Kifâye fi'l-hidâye, 338.

47 Ebü'l-Berekât en-Nesefî, Şerhu'l-'Umde, 423.

48 Teftâzânî, Şerhu'l-Makâsıd, 5/155; Sa'düddîn Mesûd b. Ömer b. Abdullah et-Teftâzânî, SSerhu'l-Akâidi'nNesefiyye, thk. Ahmed Hicâzî es-Sekkâ (Kahire: Mektebetü'l-Külliyyâti'l-Ezheriyye, 1408/1988), 74.

49 Ebû İshâk Burhâneddîn İbrâhîm b. İbrâhîm b. Hasan el-Lekânî, Umdetü'l-mürîd li-Cevhereti't-tevhîd, thk. Beşîr Bermân (Beyrut: Dârü'l-Kütübi'l-İlmiyye, 1439/2018), 4/1847.

50 Mâtürîdî, Kitâbü't-Tevhîd, 459. 
onay vermek anlamına gelecektir. Allah'ın böylesi bir durumdan münezzeh olması, kâfirlerin affını aklen muhal hale getirmektedir.

Ebü'l-Muîn en-Nesefî de burada işin kabihlik kısmına temas etmemiş olsa da benzer bir izah getirir. Bu manada küfrün asla bir serbestliğe kavuşmayacağını, haramlığının ortadan kalkmayacağını, bu yüzden hikmetin de onun cezasının affa medar olmamasını gerektirdiğini söyler. ${ }^{51}$ İlgili kimi maddelerde adeta İmam Mâtürîdî'nin mezkûr gerekçelerinin bir özetini sunan Sâbûnî de bu hususta kısa bir açıklamada bulunur. Buna göre küfür; diğer günahlardan farklı olarak suçun en uç noktasıdır. Onda bir serbestlik/ibaha ve yasaklığın kalkması gibi bir durum söz konusu olamaz. Bu yüzden onun için bir af veya bir tazminden bahsedilemez. ${ }^{52}$

Kâfirin affının aklen caiz olmadığı ifadesini hususi olarak kullanan Ebü'l-Berekât enNesefî de bu konuda İmam Matürîdî’ye izafeten diğer günahların haramlığı, yine onlara dönük cezanın kalkması aklen mümkün olsa da, küfre yönelik bir ref'in söz konusu edilmeyeceğini belirtir. Bunu da küfrün özü itibariyle kabih olması ile açıklar. ${ }^{53}$

Teftâzânî, yine küfrün affının aklen de bir imkân barındırmadığı anlayışını savunan zevatın bu görüşlerini teyit için, küfrün her daim haramlığını/yasaklığını koruyacak olmasına atıf yapıp cezasının da bu şekilde ebedi olması gerektiği yönünde kelam ettiklerini belirtir. ${ }^{54}$ İbrahim el-Lekânî de ilgili argümanı benzer şekilde açıklar. ${ }^{55}$ Şeyhzâde (öl. 1133/1721) Eş'arîler ile Mâtürîdîler arasındaki temel farklılıklardan biri olarak kâfirin affının aklen cevazı meselesine yer verdikten sonra mezkur ikinci firkanın kendi fikrini teyit için getirdiği kanıt mahiyetinde bu son maddeyi (her daim kabih mevkide bulunan küfrün cezasının ebedi olması gerektiği) zikreder. ${ }^{56}$ Mâtürîdiyye mezhebine nispet edilen bu görüşte (kâfirin affının aklen caiz olmaması), diğer kimi kaynaklar da yine bu firka mensuplarının küfrün her daim taşıyacağı kabihliği gerekçe gösterdiklerini ifade eder. ${ }^{57}$

\subsubsection{Küfrün Affının, Uygun Bir Af Konumunda Olmayacağı}

Mâtürîdî’nin kafirin ebedi azaba duçar olması gerekliliği konusunda kullandığı bir diğer argüman da yine hikmetle alakalı bir hususu içermektedir. Buna göre kâfirin affedilmesi uygun olmayan bir af pozisyonundadır. Zira o, nimet vereni inkâr etmekte, bunu da kendine hak görmektedir. İşte böyle bir kişinin bağışlanması, affın zayi edilmesi ve nimetin hükümsüz bir mevkie getirilmesi anlamına gelecektir. ${ }^{58}$ Müellifin bu yorumu da sonuç açısından ilgili affın bir nevi hikmetsizlik barındırdığı manası taşıdığı için, işbu izahı, mezkûr boyut itibariyle de kâfirin affının aklen imkânsız olduğu şeklinde yorumlamak mümkün gözükmektedir.

Sâbûnî, konuyla ilgili İmam Mâtürîdî'nin ifadelerini adeta şerh eden bir açıklama getirir. Buna göre kâfir, küfründe kendisini hak yolda görür ve buna bağlı olarak bir af ve mazeret talebinde bulunmaz. ${ }^{59}$ Hatta o, daha ileri gidip, küfrüne karşıllı bir mükâfat dahi

51 Nesefî, Tebsiratü'l-edille, 2/1065.

52 Sâbûnî, Kitâbü'l-Bidâye, 146; Sâbûnî, el-Kifâye fi'l-hidâye, 337.

53 Ebü'l-Berekât en-Nesefî, Șerhu'l-'Umde, 424.

54 Teftâzânî, Șerhu'l-Makâsıd, 5/155; Teftâzânî, Şerhu'l-Akâidi'n-Nesefiyye, 73-74.

55 İbrâhîm el-Lekânî, Umdetü'l-mürîd, 4/1847, 1857.

56 Şeyhzâde, Nazmu'l-ferâid, 31.

57 Said Fûde, "Şerh", 62.

58 Mâtürîdî, Kitâbü't-Tevhîd, 459.

59 Sâbûnî, Kitâbü'l-Bidâye, 146; Sâbûnî, el-Kifâye fi'l-hidâye, 337. 
bekler.60 Bu durumda böyle bir kişi hakkında af gibi bir hüküm olmaz/af hikmet barındırmaz.61 Müellif, Mâtürîdî’nin söz konusu izahını teyit eden bir açıklama daha yapar. Buna göre küfür en büyük suç olduğu için ona en ağır ceza verilmelidir. Buna uygun olarak kâfir, ebedi azaba muhatap olacaktır. Eğer burada küfür dışındaki bir günaha da ebedi azap cezası verilirse suç ceza dengesi bozulur, bu ise adaleti ortadan kaldırır. ${ }^{62}$ Ebü'l-Berekât enNesefî, ilgili maddeyi mukayeseli bir şekilde aktarır. Bu meyanda nimet vereni inkâr etmemesine bağlı olarak günahkârın, affı hikmet boyutuyla caiz iken; nimet sahibini reddeden, üstelik bunu hak gören kişinin affa layık bulunmadığını ifade eder. ${ }^{63}$

Söz konusu izahlardan, diğer maddelerde olduğu gibi burada da hikmet kavramının başat bir role sahip olduğu anlaşılmaktadır. Nitekim Beyâzîzâde'nin kâfirlerin affının aklen caiz olmadığını dile getirirken, bunu sadece hikmete aykırılıkla açıklaması, tam da burada vurgulanmaya çalışılan hususu teyit etmektedir. Müellifin hemen peşi sıra, aklın, hikmete aykırı olan bir şeyin caiz olmayacağına kesin bir şekilde hüküm verdiğini belirtmesi konuyla ilgili Mâtürîdî düşüncenin en güçlü ipuçlarını vermektedir.64

\subsubsection{Küfrün Affının İyilik Yapan ile Kötülük İşleyeni Eşit Hale Getirmesi}

Hem Mâtürîdî kelamcıların kendi görüşlerini temellendirirken hem de Eş'arî zevatın, bu konuda kendilerinden farklı düşünen ulemanın gerekçelerini aktarırken en sık kullandıkları argüman küfrün affının herhangi bir şekilde mümkün kategorisinde olmasının, iyilik sahibi ile kötülük sahibini eşitleyeceği, hikmetin ise bu ikisinin ayrılmasını iktiza ettiği şeklindeki kanıt olsa gerektir.

Bu manada kâfirin affının aklen caiz olmayacağı hususunda Ebü'l-Muîn en-Nesefî, daha sonra pek çok Mâtürîdî kelamcının yapacağı üzere ilk madde olarak, hikmet gereği iyilik yapan ile kötülük işleyenin ayrılması lüzumuna atıf yapar. Bunu bir kısım ayetler üzerinden teyit eder. Yine dünyada birbirinden ayrılmayan kâfir ile günahkârın ahirette; affın imkânı ve imkânsızlığı ile ebedi azaba düçar olup olmama noktasında ayrılması gerektiğini belirtir. ${ }^{65}$

Sâbûnî, kâfirin affının aklen caiz olmayacağı konusunda delil getirirken ilk aşamada hikmetin; iyilik ve kötülük sahibinin birbirinden ayrılmasını gerekli kıldığı söyler.66 Hikmete aykırı bir işin abes pozisyonuna düşeceğini, onun ise tıpkı yalan ve zulüm gibi Allah hakkında muhal olduğunu, hatta Allah'ın buna kadir olmakla bile tavsif edilemeyeceğini belirtir. ${ }^{67} \mathrm{Bu}$ hususta iyiliğin karşıllı̆ının ancak iyilik olduğu ${ }^{68}$ muhtevasındaki ayetten istidlalde bulunarak Allah'ın o ikisi arasındaki eşitliği reddettiğini dile getirir. Yine "Yoksa kötülük işleyenler kendilerini, inanıp salih amel işleyenler gibi kılacağımızı; hayatlarının ve ölümlerinin bir olacağını mı sanıyorlar? Ne kötü hüküm veriyorlar!"69 ilahi kelamı ile "Biz

\footnotetext{
60 Sâbûnî, el-Kifâye fi'l-hidâye, 337.

61 Sâbûnî, Kitâbü'l-Bidâye, 146; Sâbûnî, el-Kifâye fi'l-hidâye, 337.

62 Sâbûnî, Kitâbü'l-Bidâye, 142.

63 Ebü'l-Berekât en-Nesefî, Şerhu'l-'Umde, 424.

64 Kemâlüddîn Ahmed el-Beyâdî, İşârâtü'l-merâm min 'ibârâti'l-İmâm, thk. Ahmed Ferîd el-Mezîdî (Beyrut: Dârü'l-Kütübi'l-İlmiyye, 2007), 38.

65 Nesefî, Tebsiratü'l-edille, 2/1064.

66 Sâbûnî, Kitâbü'l-Bidâye, 146; Sâbûnî, el-Kifâye fi'l-hidâye, 336.

67 Sâbûnî, el-Kifâye fi'l-hidâye, 336-337.

68 er-Rahmân 55/60.

69 el-Câsiye $45 / 21$.
} 
müslümanları suçlular gibi kılar mıyız?70 ayetinin de aynı manayı teyit ettiğini kaydeder. ${ }^{71}$ Müellifin, Eș'arîlerin kâfirlerin affının aklen caiz olduğu fikrini reddederken, sem'î delillerin de bu affın aklen caiz olmadığına delalet ettiğini belirtmesine bakllacak olursa o, ilgili ayetlerden böyle bir yorum da çıkartmış olmalıdır. ${ }^{72}$ Bu konuda Ebü'l-Berekât en-Nesefî de benzer ifadeler kullanarak ilgili ayetlerden istidlal yapar. ${ }^{73}$

Mâtürîdî ulema, kâfirlerin affını, iyi ile kötüyü eşit hale getireceği üzerinden reddetme aşamasında söz konusu ayetlerden istidlalde bulundukları gibi, Eş'arîlerin bu affın aklen caiz olduğu hususunda Hz. Îsâ'nın teslise düşen Hıristiyanlar hakkında "Ĕger onlara azap edersen, şüphe yok ki onlar senin kullarındır. Eğer onları bağışlarsan, yine şüphe yok ki sen mutlak güç sahibisin, hüküm ve hikmet sahibisin"74 kullandığı ifade üzerinden yaptıkları istidlale karşı da cevap mahiyetinde açıklama getirirler. Eş'arîlerin, söz konusu ayette, dâhil olduğu fiilin ihtimal barındırdığına işaret eden "in" edatı kullanılmasından, burada kâfirlere dönük bir af ihtimalinin mevzu bahis edilebileceği şeklindeki yaklaşımına karșı, ${ }^{75}$ hususi bir mahiyette değilse de İmam Mâtürîdînnin yaptığı açılklama, bir cevap niteliği taşımaktadır. Mâtürîdî, mezkûr ayetin tefsirinde yer verdiği görüşlerde, azap edilenleri; bu kötü söz üzere kalıp ölen, mağfiret olanları, hidayetle müşerref olan kimseler şeklinde aktarır. Böylece o, Eş'arîlerin söz konusu ayette kâfir olarak ölenlere dönük de bir af ihtimalinin belirebileceği şeklindeki düşüncelerini reddetmiş, affa uğramanın teslis düşüncesinden dönen kimselere mahsus olduğunu ortaya koymuş olur. ${ }^{76}$

Yukarıdaki tavrın bir benzerini Ebü'l-Berekât en-Nesefî de sergiler. 0 da Hz. Îsâ'nın bu kişiler arasından küfrünü sürdüreceklerin de imana geleceklerin de olacağını bildiğini, ilgili ifadeleri bu doğrultuda kullandığını, dolayısıyla burada bağışlanacaklardan kastın işte bu iman edecekler olduğunu belirtir. Peşi sıra gelen "hakîm" ifadesini de, ancak hikmet çerçevesinde kulları cezalandıran şeklinde yorumlayarak, kâfirin affının aklen caiz olmayacağını ihsas eder. ${ }^{77}$

Sabûnî, el-Kifâye eserinde benzer muhtevada bir gerekçeye daha değinir. Bu manada dünya yaşantısında aralarında fark olmayan kâfir ile müminin ahirette birbirinden ayrılması gerektiğini söyler. Müminin cehennemde, kâfirin cennette ebedi kalmasının zulüm olacağını, bunun ise Allah hakkında muhal olduğunu belirtir. Bunun zulüm olmasını ise zulmün tarifi üzerinden ortaya koyar. Bu manada zulmü bir şeyi kendi mevkii dışına koymak olarak tanımlar. Böylece mümin ve kâfire yapılacak söz konusu muamelenin bu duruma uyduğunu ihsas etmiş olur. ${ }^{78}$

Sâbûnî, iyilik sahibine iyilik, kötülük sahibine ceza ile karşıllı verilmesini hikmet olarak gösterdiği gibi, bunu adalet olarak da takdim eder. Bu meyanda aksi bir davranışın yine zulüm olacağını beyan eder. Onun Allah hakkında muhal olduğunu belirtir. Burada yine

70 el-Kalem 68/35.

71 Sâbûnî, Kitâbü'l-Bidâye, 146; Sâbûnî, el-Kifâye fi'l-hidâye, 337.

72 Sâbûnî, Kitâbü'l-Bidâye, 145.

73 Ebü'l-Berekât en-Nesefî, Şerhu'l-'Umde, 422-423.

74 el-Mâide 5/118.

75 İbnü'l-Müneyyir, el-Intisâf, 317.

76 Mâtürîdî, Te'vîlâtü'l-Kur'an, 4/376-377.

77 Ebü'l-Berekât Hafizüddîn Abdullah b. Ahmed b. Mahmûd en-Nesefî, Tefsîrü'n-Nesefî=Medârikü't-tenzîl ve hakâikü't-te'vîl, thk. Yûsuf Ali Büdeyvî-Muhyiddin Dîb Müstû (Beyrut: Darü'l-Kelimi't-Tayyib, 1419/1998), 1/487.

78 Sâbûnî, el-Kifâye fi'l-hidâye, 337. 
şahit âlemde söz konusu davranışın abes olarak niteleneceğine işaretle Allah'ın böyle bir şeyden tenzihinin gerekli olduğunu, bu durumun "aklen caiz" veya "mülkünde tasarruf" şeklinde yorumlanamayacağını dile getirir. Bunu da; hakîm olan bir varlı̆̆ın mülkündeki tasarrufunun da, yine hikmet ve doğru yol üzere olması gerektiği hususu ile izah eder. Hikmete aykırı bir yol izlemenin Allah hakkında muhal olan sefehliğe sebebiyet vereceğini ilave eder.79

Çalışmanın bu aşamasında söz konusu ifadelerin yorumu mahiyetinde İbn Teymiyye'nin Minhâcü's-sünne eserinin bir nüshasında bulunan bir talikteki önemli bir tespiti de burada aktarmak uygun olacaktır. Söz konusu talikte, hakîm olan varlığın sadece hikmetli şekilde tasarrufta bulunacağına dönük ișbu fikrin, Ehl-i sünnet'ten ancak (fiillerde) illet, sebep, hikmet ve maslahat gözeten kimselerin görüşü olabileceği zikredilir. Buna Mâtürîdîler örnek gösterilir. Eş'ariyye gibi ilgili hususları kabul etmeyen fırkaların ise işi "mahza meşiet" ile açıkladıkları belirtilir. Yine Mâtürîdîler gibi hüsün/iyinin aklî olduğunu savunanların, O'nun mülkündeki tasarrufunun, ancak aklî düstura uygun olduğunda hüsün olacağı fikrine yöneldikleri kaydedilir. Bu yüzden onların kâfirin affını aklen de tecviz etmedikleri vurgulanır.80

Muhtemelen Sâbûnînin ifadelerinden yararlanan Ebü'l-Berekât en-Nesefî de meseleyi neredeyse aynı șekilde dile getirir. Sadece böyle bir işin zulüm olduğunu ifade ile yetinmez, bunun aynı zamanda iyilik sahibine kötülük, kötülük sahibine de iyilik anlamına geleceğini ilave eder. ${ }^{81}$ Bâbertî de aynı konu etrafında ilgili nasların ahirette Müslümanlar ile kâfirlerin eşit olamayacağını beyan ettiğini söylerken benzer bir vurgu yapmış olur. Nitekim onun bu hususta ayrıca, iyilerle kötülerin farklı değerlendirileceği muhtevasındaki ayetlere atıf yapması, peşi sıra da hikmetin; Allah'ı bilenin, bilmeyene üstünlüguünü gerektirdiği, günahkârın ebediyen cehennemde kalmasının iyi ile kötünün eşitlenmesi, bunun ise imanın hiçbir faydasının bulunmamasını iktiza edeceği yönünde açıklama getirmesi bu hususu teyit etmektedir.82 İbnü'l-Hümâm da Mâtürîdîlerin konuya yaklaşımının temel gerekçesini aktarırken, yine aynı maddeye yer verir. Bunu bir kısım ayetler ile teyit ettiklerini söyler. ${ }^{83}$

Teftâzânî yine, kim olduğunu belirtmeksizin küfrün affının aklen cevazına karşı çıkanların bu konuda bazı argümanlar kullandıklarını söyleyip bunları sayarken onların ilkin, küfrün affına; bunun oldukça güzel işler yapanlar ile tam aksi şekilde davranan kimseler arasındaki farkın kalkmasına neden olacağı, bunun ise hikmete aykırılık teşkil edeceği şeklinde bir delil getirdiklerini belirtir. Ancak bunun zayıf bir görüş olduğunu söylemeden de geçemez. ${ }^{84}$ Teftâzânî söz konusu gerekçeyi Nesefi akaidine yaptığı şerhte de ilk madde olarak zikreder. Ancak bu kez herhangi bir yorum yapmaz. ${ }^{85}$

\footnotetext{
79 Sâbûnî, el-Kifâye fi'l-hidâye, 337.

80 Bu talik sahibi meçhul olduğu için burada sadece ilgili ifadelerin geçtiği eserin künyesi zikredilecektir. Tekrar vurgulamak gerekir ki, söz konusu eser İbn Teymiyye'ye ait ise de bu görüş, onun fikri değildir. Ebü’l-Abbas Takıyyüddîn Ahmed b. Abdülhalim İbn Teymiyye, Minhacü's-sünneti'n-nebeviyye, thk. Muhammed Reşâd Salim (Riyad: Câmiatü'l-İmam Muhammed b. Suûd el-İ́slâmiyye, 1986/1406), 2/305.

81 Ebü'l-Berekât en-Nesefí, Șerhu'l-'Umde, 423.

82 Bâbertî, Serhü'l-Akîdeti't-Tahâvî, 104-105.

83 İbnü'l-Hümâm, el-Müsâyere, 112.

84 Teftâzânî, Serhu'l-Makâsıd, 5/148-149.

85 Teftâzânî, Şerhu'l-Akâidi'n-Nesefiyye, 73.
} 
Küfrün affının aklen caiz olduğunu düşünen bir zat olarak Teftâzânî'nin böyle bir yorum getirmesi doğaldır. Onun bu delili zayıf görmesi, Allah'ın iyi ile kötü arasındaki farkı tespit için böyle bir araca ihtiyacı olmadığı düşüncesine mebni olmalıdır. Açıkçası kullarını imtihan etmeden, onlar daha bir davranış sergilemeden Allah'ın iyi ile kötüyü bileceğine dair Mâtürîdî ulemanın da elbette hiçbir şüphesi yoksa da, onların hikmete ağırlık vermeleri, hikmetin kişinin neden cezaya çarptırıldığını bilmesini gerektirmesi, onları böyle bir görüşe sevketmiş olmalıdır.

Teftâzânî, yine konuyu tartıştığı bir bölümde bir vesileyle günahkârın affı ile kâfirin affı arasında aklî cevaz hususunda ayrım yapanların hikmet zaviyesinden konuya yaklaşıp bu ikinci affı caiz görmediklerini aktarırken onların tutundukları bazı kanıtlara yer verir. Burada onların "Biz müslümanları suçlular gibi kılar mıyız?"86 gibi kimi ayetlerin ihsas ettiği üzere, bir ayrım yapılmamasının hikmete aykırılık teşkil edeceği kanıtına başvurduklarını söyler. Bu hususu teyit için günahkâr ile kâfir arasındaki farklara dikkat çektiklerini, bu anlamda kâfirden farklı olarak günahkârda bir azap korkusu ile rahmet ümidi ve hevasına tabi olarak işlediği günahlara karşılık bir kısım güzel işler yapma gibi haller bulunduğuna dikkat çektiklerini belirtir. ${ }^{87}$ İlgili gerekçe, hatırlanacağı üzere İmam Mâtürîdî'nin kâfirin neden ebedi cezaya müstahak olması gerektiğini izah için yer verdiği bir maddedir.

Eş'arî âlimi İbrahim el-Lekânî de aynı şekilde isim vermeksizin küfrün affını aklen imkânsız görenlerin bu konuda ilgili ayetlerden yararlanarak, aksi bir düşüncenin iyi ile kötünün ayrılmasını gerektiren hikmete zıtlık teşkil edeceğine atıf yaptıklarını belirtir. ${ }^{88}$ Başka bir yerde bu hususu daha çarpıcı şekilde dile getirir. Bu meyanda onların kâfirin affının caiz olmamasını; hikmete aykırı olan en iyi ile en kötüyü eşit hale getirme teziyle reddettiklerini söyler. ${ }^{89}$

Eş'ariyye mezhebinin bu konudaki görüşünün kendisine daha sevimli geldiğini söyleyen İbnü'l-Hümâm, Mâtürîdîlerin söz konusu hikmete aykırılık iddiasını zan şeklinde niteleyip bunun "kâfirin azaba uğrayacağı ittifakla (șer'î naslar itibariyle) kesindir, bu hüküm hikmete mebni verilmiştir, o halde kâfirin affı/azap edilmemesi hikmete aykırıdır" şeklindeki yanlış fikirlerine dayandığını belirtir. Buna bir cevap verir. Ona göre bir şeyin iki zıt hal ile iliş̧isi şahit âlemde de akılda da bellidir. İşbu durum üzerinden örnek verildiğinde bir melik, düşmanını yendiğinde ya (ona olan öfkesini çıkarmak için) onu öldürür, ya da hiçbir değerinin olmadığını göstermek için affeder. Allah'ın öfkesini azap yoluyla çıkarmak gibi bir durumla tavsifi muhaldir. ${ }^{90}$ Bu yorumuyla müellif, Allah'ın kâfiri affetmesinin en azından mümkün olduğunu söylemiş olur. Murtazâ ez-Zebîdî de (öl. 1205/1791) katıldığını ihsas eder şekilde İbnü'l-Hümâm'ın yukarıdaki yorumunu uzun uzadıya aktarır. ${ }^{91}$

Mâtürîdî olan İbnü'l-Hümâm el-Müsâyere eserinde işbu konuda Eş'arî anlayışı kabul ederken, bu eserin Eş'arî șarihi İbn Ebû Şerîf ise (öl. 906/1500) Mâtürîdî görüşü benimser. Bu noktada İbn Ebû Şerif, Eş'arî görüşün kendisine daha güzel geldiğini söyleyen İbnü'lHümâm'a karşı, kendisine ise bu fikrin daha nahoş göründügünü belirtir. Verdiği melik örneğinden hareketle Allah'ın kâfirleri affetmesinin hiç de yabana atılmayacağını ihsas eden

\footnotetext{
86 el-Kalem 68/35.

87 Teftâzânî, Şerhu'l-Makâsıd, 5/155.

88 Lekânî, Umdetü'l-mürîd, 4/1857.

89 Lekânî, Umdetü'l-mürîd, 4/1847.

90 İbnü'l-Hümâm, el-Müsâyere, 114-115.

91 Zebîdî, Kitabu İthafü's-sadeti'l-muttakîn, 2/186.
} 
İbnü'l-Hümâm'a karşı, melikin affettiği o düşmanın, memlekette fesat çıkarma ve melikin yakınlarına eziyet verme ihtimalinin hatırdan çıkarılmaması gerektiğini ima eder. Sonrasında işi konuyla alakalı hale getirerek, Allah'ın kâfiri affetmesinin de hikmetin gereği olan iyi ile kötünün ayrılmasını ortadan kaldıracağını belirtir. ${ }^{92}$

\section{SONUC}

İmam Mâtürîdî ile başlayan, onun yolunu izleyenlerce devam ettirilen küfrün affının aklen caiz olmaması anlayıșı, bir takım maddeler üzerinden gerekçelendirilmiștir. Ayrıntıda birbirinden farklı olsa da, genel anlamda hikmet kavramı üzerine yoğunlașan bu gerekçelerde, söz konusu affın muhaliyetinin özünden dolayı değil, bir sebebe mebni bu pozisyonda olduğu izlenimi oluşmaktadır. Her ne kadar mesele, doğrudan aklen caiz olmama şeklinde sunulmuş olsa da, belli ki burada iki zıddın içtimaı gibi özünde muhal olan değil, hikmetsizliğe yahut abesliğe sebebiyet verme gibi harici bir durum nedeniyle muhaliyet gerçekleşmektedir. Diğer bir ifade ile burada muhâl bi'z-zât değil, muhâl bi'l-gayr söz konusu olmaktadır.

Mâtürîdiyye'nin bu anlayışından gidildiğinde Allah üzerine vacip olmayan, ancak ilah olması itibariyle kendisine uygun şekilde davranılması gereken hikmet, sözde değilse de, özde adeta O'na vacip olmaktadır. Bu anlayıș onları Mu'tezilî hikmet görüșüne yakınlaştırmaktadır. Mu'tezile mezhebinde hikmet Allah'a vacip kılınırken, bunun onların işbu hikmeti birilerinin -hâşâ- Allah'a dikte etmesi șeklinde değil, ilahlığının bir gereği olarak anlaşılması lüzumuna yönelik vurgular dikkate alındığında açıkçası, MâtürîdîMu'tezilî hikmet anlayışı birbirine daha da yaklaşmış olmaktadır. Aradaki fark, ilkinin lafzen reddettiği zorunluluğu, ikincisinin açık bir şekilde O'na nispet etmesinden ibaret kalmaktadır. Bu da temelde çok da güçlü bir farklılık olmasa gerektir.

Mâtürîdîlerin konuyla ilgili tavrına bakıldığında, onların naslardan genel anlamda çıkardıkları Allah tasavvurunu, kâfirin affının aklen imkânı gibi hususi manada kendisine dair açık bir hüküm bulunmayan bir meselede ısrarlı şekilde yansıtmaya çalıştıkları dikkat çekmektedir. Kelamın farklı kanaatler beslemeye uygun, diğer ifadesiyle içtihada elverişli olan bir konusunda böylesi bir tavır almanın yadırganacak bir tarafı olmadığını belirtmek gerekir. Bu tutumu diğer kimi itikadi firkalara da aynı şekilde teşmil etmek mümkündür. Bu noktada belki tartışma mevzuu edinilmesi gereken husus; ilgili ilah tasavvurunun naslara muvafakat nispetini tespit etmektir. Ancak açıkçası bunun da tam anlamıyla objektif bir tespitini yapmak pek de mümkün gözükmemektedir.

Şüphesiz Mâtürîdî düşüncede küfrün affının aklen muhaliyet barındırmasının, onların akla oldukça güçlü bir misyon yüklemeleriyle de yakından bir ilişkisi vardır. Küfür gibi özünde hiçbir hayır içermemesi itibariyle safi kötü bir durumun, adalet ve hikmet gereği affa medar olmayacağına dönük vurgu, ilgili hususları aklın da tespit edeceğine yönelik fikirden bağımsız olmasa gerektir. Küfrün affının olmadığına dair ilgili naslar, aslında Eş‘arîleri de bu haliyle küfrün kabihliğini kabul durumunda bıraksa da, bunun bir diğer ilahi irade yahut buyrukla başka bir konuma geçmesi imkânsızlık barındırmadığı için, onlarda sabit olmayan, değişken bir hüsün-kubuh anlayışı ortaya çıkmaktadır. Onların iyi ve kötüye böyle bir alan açmaları, tamamen ilahi iradeyi bir tahdit altına almama anlayışıyla alakalıdır. Bunun ise Mâtürîdî düşüncede kabulü pek de mümkün gözükmemektedir. Kimi

92 Ebü’l-Meâlî Kemaleddîn Muhammed b. Muhammed b. Ebî Bekr İbn Ebî Şerîf, el-Müsâmere bi șerhi'l-Müsâyere (Bulak: Matbaatü'l-Kübra'l-Emîriyye, 1317), 176-180. 
ilim ehlinin vurguladığı üzere, Mâtürîdiyye'nin ilahi naslarda kendisine yer bulan küfrün affının mevzu bahis olmayacağı şeklindeki ilgili ifadeleri, hakîm olan ilah tarafından kullanıldığı için, burada aksi ihtimalin (küfrün affı) söz konusu edinilebilmesi, O'nun hikmetini de sorgulatır hale getirecektir. Allah'ın sefeh ve abeslik ile hemhal olabilmesinin imkânsızlığı, işte bu duruma sebebiyet verecek küfrün affını da imkânsız hale getirmektedir.

Mâtürîdî düşünce sistemi bir arada düşünüldügünde bu ekole mensup olanların kâfirin affına aklen de cevaz vermemeleri, doğruluğu yanlışlığı bir tarafa, onlar adına tutarlılığın da bir gereğidir. Onların hüsün kubuh, hikmet ve vâidden dönme meselelerinde savundukları görüș, kâfirin affına hiçbir açık kapı bırakmamalarına da zemin hazırlamıștır. Öte yandan yine Mâtürîdî ulemanın kulun kendi fiilini gerçekleștirme, bu meyanda iman etme ve küfre düşme hususunda özgür iradeye sahip olduğuna dönük yaptıkları güçlü vurgular da, ettiğini bulma gibi bir mantık içerisinde kâfirin yaptığı işin karşılığını alması, bu bağlamda affa medar olmaması anlayışını da beraberinde getirmiş olsa gerektir. $\mathrm{Bu}$ durum da açıkçası onların mezkûr iki meselede birbiriyle uyumlu bir anlayışın savunuculuğunu yaptıklarına işarettir. Bütün birbiriyle uyumlu bu fikirler de zaten onları aklı ve nakli birbirini destekler şekilde kullanan sistemli bir mezhep haline getirmiş, buna bağlı olarak da ardında pek çok Müslümanı cem etmiştir.

\section{KAYNAKÇA}

Bâbertî, Ebû Abdullah Ekmeleddîn Muhammed b. Muhammed. Şerhü'l-Akîdeti'tTahâvî. tlk. Abdüsselâm b. Abdülhâdî Şennâr. [Beyrut]: Dârü'l-Beyrûtî, 1430/2009.

Beyâdî, Kemâlüddîn Ahmed. İşârâtü'l-merâm min 'ibârâti'l-İmâm. thk. Ahmed Ferîd el-Mezîdî. Beyrut: Dârü'l-Kütübi'l-İlmiyye, 2007.

Beyzâvî, Ebû Saîd Nâsırüddîn Abdullah b. Ömer b. Muhammed. Envârü't-tenzîl ve esrarü't-te'vîl. thk. Muhammed Abdurrahman el-Maraşl. 5 Cilt. Beyrut: Dâru İhyâi't-Türâsi'lArabî, ts.

Beyzâvî, Ebû Saîd Nâsırüddîn Abdullah b. Ömer b. Muhammed. Tavâli'u'l-envâr min metâli'i'l-enzâr. thk. Abbas Süleyman. Beyrut: Dârü'l-Cîl; Kahire: el-Mektebetü'l-Ezheriyye li't-Türâs, 1411/1991.

Ebû Azbe, Hasen b. Abdülmuhsin. er-Ravzatü'l-behiyye fî mâ beyne'l-Eşấ'ire ve'lMâtürîdiyye. Haydarabad: Dâiretü'l-Maârifi'n-Nizamiyye, 1322.

Endelüsî, Ebû Hayyân Muhammed b. Yûsuf b. Alî b. Yûsuf b. Hayyân. Tefsirü'l-Bahri'lmuhit. Adil Ahmed Abdülmevcûd-Ali Muhammed Muavvız. 8 Cilt. Beyrut: Dârü'l-Kütübi'lİlmiyye, 1413/1993.

Eş'arî, Ebü'l-Hasen. Makâlatüll-İslâmiyyîn ve ihtilâfü'l-musallîn. thk. Muhammed Muhyiddîn Abdülhamid. 2 Cilt. Kahire: Mektebetü'n-Nehda'l-Mısriyye, 1950.

Fûde, Said Abdüllatif. “Şerh”. Mesâilü'l-ihtilâfbeyne'l-Eşâ'ire ve'l-Mâtürîdiyye. thk. Said Abdüllatif Fûde. 9-77. Amman: Dârü'l-Feth, 1430/2009.

İbn Ebî Şerîf, Ebü'l-Meâlî Kemaleddîn Muhammed b. Muhammed b. Ebî Bekr. elMüsâmere bi şerhi'l-Müsâyere. Bulak: Matbaatü'l-Kübra'l-Emîriyye, 1317.

İbnü'l-Hümâm, Kemâleddin Muhammed b. Abdülvahid b. Abdülhamid. el-Müsâyere fí ilmi'l-kelâm. Kahire: el-Mektebetü'l-Mahmûdiyyeti't-Ticâriyye, 1348/1929. 
İbnü'l-Müneyyir, Ebü'l-Abbas Nasırüddîn Ahmed b. Muhammed. el-İntisâf fî mâ tedammenehü'l-Keșşâf mine'l-i 'tizâl. tlk. Halil Me'mun Şeyha. Beyrut: Dârü'l-Marife, 3. Basım, 1430/2009.

Ka'bî, Ebü’l-Kâsım Abdullah b. Ahmed b. Mahmûd el-Belhî. Kitâbü'l-Makâlât ve meahû uyûnül-mesâil ve'l-cevâbât. thk. Hüseyin Hansu-Racih Kürdi-Abdülhamid Kürdi. İstanbul: İstanbul 29 Mayıs Üniversitesi Kur'an Araştırmaları Merkezi (KURAMER); Amman: Dârü'lFeth, 1439/2018.

Kâdî Abdülcebbâr, Ebü'l-Hasen Abdülcebbâr b. Ahmed. Şerhu'l-Usûli'l-hamse. thk. Abdülkerim Osman. Kahire: Mektebetü Vehbe, 3. Basım, 1416/1996.

Kemalpaşazâde, İbn Kemal Ahmed Şemseddin. Mesâilü'l-ihtilâf beyne'l-Eşấire ve'lMâtürîdiyye. thk. Said Abdüllatif Fûde. Amman: Dârü'l-Feth, 1430/2009.

Lekânî, Ebû İshâk Burhâneddîn İbrâhîm b. İbrâhîm b. Hasan. Umdetü'l-mürîd liCevhereti't-tevhîd. thk. Beşîr Bermân. 5 Cilt. Beyrut: Dârü'l-Kütübi'l-İlmiyye, 1439/2018.

Mâtürîdî, Ebû Mansûr Muhammed b. Muhammed b. Mahmûd Mâtürîdî Semerkandî. Kitâbü't-Tevhîd. thk. Bekir Topaloğlu-Muhammed Arûçî. Beyrut: Dâru Sâdır; İstanbul: Mektebetü'l-İrşad, ts.

Mâtürîdî, Ebû Mansûr Muhammed b. Muhammed b. Mahmûd Mâtürîdî Semerkandî. Te'vîlâtü'l-Kur'an, thk. Mehmet Boynukalın v.dğr. 18 Cilt. İstanbul: Mîzân Yayınevi, 20052011.

Mestçizâde, Abdullah b. Osman b. Musa Efendi. el-Mesâlik fi'l-hilafiyyât beyne'lmütekellimîn ve'l-hükemâ. thk. Seyyid Bagcevan. Beyrut: Dâru Sâdır; İstanbul: Mektebetü'lİrşâd, 1428/2007.

Nesefî, Ebü'l-Berekât Hâfizüddîn Abdullah b. Ahmed b. Mahmûd. Şerhu'l-'Umde fí akîdeti Ehli's-sünne ve'l-cemâa' thk. Abdullah Muhammed Abdullah İsmail. Kahire: elMektebetü'l-Ezheriyye li't-Türâs, 2011.

Nesefî, Ebü'l-Berekât Hâfızüddîn Abdullah b. Ahmed b. Mahmûd. Tefsîrü'nNesefî=Medârikü't-tenzîl ve hakâikü't-te'vîl. thk. Yûsuf Ali Büdeyvî-Muhyiddin Dîb Müstû. 3 Cilt. Beyrut: Darü'l-Kelimi't-Tayyib, 1419/1998.

Nesefî, Ebü'l-Muîn Meymûn b. Muhammed b. Muhammed. Kitabü't-temhîd li kavâidi'ttevhîd. thk. Habîbullah Hasan Ahmed. Kahire: Dârü't-Tıbâati'l-Muhammediyye, 1986.

Nesefî, Ebü'l-Muîn Meymûn b. Muhammed b. Muhammed. Tebsiratü'l-edille fí usûli'ddîn. thk. Muhammed Enver Hamid Îsâ. 2 Cilt. Kahire: el-Mektebetü'l-Ezheriyye li't-Türas, $1432 / 2011$.

Özgen, Mustafa. Eş'arî ve Mâtürîdî Mezhepleri Arasındaki Görüş Farkları. Konya: Palet Yayınları, 2017.

Pezdevî, Ebü'l-Yüsr Muhammed b. Muhammed b. Hüseyin. Usûlü'd-dîn. thk. Hans Peter Linss. Kahire: el-Mektebetü'l-Ezheriyye li't-Türas, 1424/2003. 
Râzî, Ebû Abdillah Fahreddîn Muhammed b. Ömer Fahreddîn. Tefsîru'l-Fahri'r-Râzî. 32 Cilt. Beyrut: Dârü'l-Fikr, 1981.

Sâbûnî, Ebû Muhammed Nuruddîn. el-Kifâye fi'l-hidâye. thk. Muhammed Arûçî. Beyrut: Dârü İbn Hazm; İstanbul: Türkiye Diyanet Vakfı İslam Araştırmaları Merkezi (İSAM), 1435/2014.

Sâbûnî, Ebû Muhammed Nuruddîn. Kitâbü'l-Bidâye mine'l-kifâye fi'l-hidâye fi usûli'ddîn. thk. Fethullah Huleyf. Kahire: Dârü'l-Maârif, 1969.

Şeyhzâde, Abdürrahim b. Ali. Nazmu'l-ferâid ve cem'u'l-fevâid. Kahire: Matbaatü'lEdebiyye, 1317/1899.

Teftâzânî, Sa'düddîn Mesûd b. Ömer b. Abdullah. Şerhu'l-Akâidi'n-Nesefiyye. thk. Ahmed Hicâzî es-Sekkâ. Kahire: Mektebetü'l-Külliyyâti'l-Ezheriyye, 1408/1988.

Teftâzânî, Sa'düddîn Mesûd b. Ömer b. Abdullah. Şerhu'l-Makâsıd. thk. Abdurrahman Umeyre. 5 Cilt. Beyrut: Âlemü'l-Kütüb, 2. Baskı, 1419/1989.

Timurtâşî, Şemseddîn Muhammed b. Abdullah b. Ahmed el-Gazzî. Muînü'l-müftî ala cevâbi'l-müsteftî. thk. Mahmud Şemseddin Emir el-Hazzai. Beyrut: Darü'l-Beşairi'lİslamiyye, $1430 / 2009$.

Yüksel, Emrullah. Mâtürîdîler ile Eş‘arîler Arasındaki Görüş Ayrılıkları. İstanbul: Düşün Yayıncilık, 2012.

Zebîdî, Ebü'l-Feyz Murtaza Muhammed b. Muhammed b. Muhammed. Kitâbu İthâfü's-sadeti'l-muttakîn bi-şerhi esrâr-ı İhyâi ulûmi'd-dîn. 10 Cilt. Beyrut: Müessesetü't-Târîhi'l-Arabî, 1414/1994. 